\title{
Study on the Influence of Students' Value Co- creation Behaviour on the Brand Image of Private Colleges and Universities
}

\author{
Yiheng Wang ${ }^{1,2, *}$ \\ ${ }^{1}$ Macau University of Science and Technology, Macau, China \\ ${ }^{2}$ Zhuhai University of Science and Technology, Zhuhai, Guangzhou, China \\ *Corresponding author. Email: 279951356@qq.com
}

\begin{abstract}
In the context of education marketization, the relationship between private colleges and universities and their students is gradually evolving into one between enterprises and consumers, and students, as consumers, have more initiative and choices. The fierce market competition requires private colleges and universities to constantly improve their comprehensive strength to meet the market demand. As an external manifestation of the comprehensive strength of private colleges and universities, brand image will have an important impact on consumers' perception and behaviour, and is the main weapon for colleges and universities to distinguish themselves from competitors. Students' value co-creation behaviour is beneficial for private colleges and universities to better understand and timely provide what students need. Therefore, it is of great significance for the long-term development of private colleges and universities to carry out research on the correlation between the brand image of private colleges and the theory of student value co-creation and the influence of brand image.
\end{abstract}

Keywords: Private colleges and universities, Value co-creation behaviour, Brand image.

\section{INTRODUCTION}

With the continuous development and expansion of the education market, colleges and universities have now entered the stage of market segmentation, in which each one of them has to find its own positioning and constantly strengthen its own characteristics. The evolution history of higher education in the world proves that any successful and first-class university is a university with its own characteristics. A university without characteristics is bound to lack competitiveness and vitality, thus losing the basis for sustainable development, not to mention popularity and reputation. Therefore, in the process of building the brand image of private colleges and universities, cultivating the brand characteristics is an important part of its brand construction, and the brand characteristics and personality of private colleges and universities are the externalization of the essence of higher education. A good brand image is the symbol of a university to obtain public trust, and it is the unity of the internal quality and external performance of a university. Introducing students' value co-creation behaviour in the process of brand image construction can provide constructive reference for the construction of private colleges and universities, which will bring direct economic benefits to the college or university, and promote the private them to make new breakthroughs stably.

\section{RESEARCH ON THE BRAND IMAGE OF PRIVATE COLLEGES AND UNIVERSITIES}

\subsection{Brand Image}

Historically, brands evolved from the marketing of physical products (Chaudhry, Gupta \& Chauhan, 2017). A brand is more than just a name; it is an identification mark that adds unique value and personality to a product (Marconi, 1993; Aaker, 1997). Brand image refers to consumers' perception and emotion towards the brand, which is usually the determinant of their cognition, emotion and attitude 
towards the brand (Cho, Fiore \& Russell, 2015); brand image is anything connected with the brand in consumers' memory, and it is their comprehensive cognition and evaluation of an objective thing, which is one of the main bases for consumers to distinguish competing brands.

\subsection{Brand Image of Private Universities}

Private colleges and universities refer to institutions of higher learning and other educational institutions established by enterprises, institutions, social organizations, other social organizations and individual citizens with non-state financial educational funds. As an important part of higher education, private colleges and universities have a series of problems, such as a late start, insufficient cultural precipitation and insufficient public credibility, compared with public colleges and universities. Although private colleges and universities imitate public colleges and universities at the beginning of their establishment, from specialty settings to campus environment, they just cannot imitate the unique brand image. Therefore, the construction of the brand image of private colleges and universities is imminent. The brand image of private colleges and universities refers to a comprehensive cognition and evaluation by social groups on the school spirit, talent cultivation ability, faculty strength, social reputation and other aspects of the institution. As a carrier of the comprehensive quality of private colleges and universities, brand image significantly affects consumers' decision-making willingness (Chen, Chen \& Huang, 2012). "As universities are increasingly influenced by competitive market forces, marketing will become increasingly important in creating a favourable institutional image, which will benefit students and staff" (Wilkins \& Huisman, 2015, pp.1256-1257). In the context of education marketization, private colleges and universities are transforming into an organization that provides educational services to achieve the goal of profit. In order to attract more potential students, the role of brand image cannot be ignored. Based on the above viewpoints, this paper carries out the research taking brand image as the theoretical background.

\subsection{Present Situation of Brand Image Development of Private Colleges and Universities}

Studies have shown that the marketization of higher education has become a global phenomenon, especially in those English-speaking countries (Hems-Lee-Brown \& Oplatka, 2006). In such an environment of fierce competition, private colleges and universities need to build their own brand more perfectly with maximum validity in the process of development if they are to stand out from many colleges and universities (Binsardi \& Ekwulugo, 2003; Lin, Lin \& Wang, 2020) to highlight its competitive advantages and school-running characteristics (Hewer, Brownlie \& Kerrigan, 2013). Otherwise, the private colleges and universities lacking innovation and market competitiveness are easily eliminated by the market will be eliminated by the market. Therefore, now more and more scholars begin to pay attention to this problem, and many private universities are also constantly seeking for changes and innovations in the development.

However, in such a fierce market competition environment, brand image has not been implemented as an important strategy to be distinguished from competitors by private universities in China. First of all, because of the late emergence of private colleges and universities, private colleges and universities in China tend to have young brands, and have low awareness in brand building. As a result, China's private colleges and universities are facing serious problems of homogenization in terms of specialty settings and fees. Besides, in the process of brand image construction, there are some problems in different colleges and universities, such as unclear classification, unclear positioning, lost features, convergent goals, blind pursuit of class promotion and "largeness and comprehensiveness" in subject setting. Blind brand building of the private colleges and universities leads to their failure to create a distinctive brand or leave an impression in the minds of students' parents and people from all walks of life after spending a lot of manpower and material resources. This means that the brand cannot give full play to its due value, which is not conducive to the sustainable development of private colleges and universities. What's more, some private colleges and universities invest little in external publicity and have a small scope of publicity. They only rely on the competitiveness of their parent universities and lack the competitiveness of private colleges and universities themselves, leading to a low brand influence and brand recognition in society, which means the image cognition of students and parents to private colleges and universities cannot match the actual quality of running schools. This directly causes the 
failure of private colleges and universities to give full play to its characteristics and attract more talents. As a kind of service product, education has no physical product as the carrier, and students' understanding of it almost completely depends on brand image. Therefore, the establishment of the brand image of private colleges and universities should be regarded as an important stage in the process of their overall construction and development.

\section{STUDY ON STUDENTS' VALUE CO-CREATION BEHAVIOUR}

\subsection{Value Co-creation Theory}

Value co-creation is a new method of value creation, that is, the theory that consumer and enterprise jointly create value with individual as the center. Prahalad \& Ramaswamy (2004) jointly proposed to define the value co-creation theory as an activity in which enterprises and customers jointly create value, emphasizing that it is a "process of integrating existing resources from various service systems to create value". Value cocreation theory breaks the traditional view that enterprises are value creators and consumers are passive value receivers. The participation of consumers in the consumption process enables enterprises to develop products that are more in line with the needs of consumers (Lengnick-Hall, 1996; Ennew \& Binks, 1999). Value co-creation is of great significance to both enterprises and consumers. For enterprises, through value cocreation, they integrate the wisdom and thoughts of numerous consumers in new product development, service upgrading and potential market development (Yi \& Gong, 2013), and the advantage brought by this kind of intelligent information collection is the competitive advantage that distinguishes the enterprise from other competitors.

\subsection{The Value Co-creation Behaviour of Private Colleges and Universities Students}

Based on the value co-creation theory, Yi \& Gong (2013) divided value co-creation behaviour into participation behaviour and citizenship behaviour in their research. Participation behaviour is the behaviour within the role, including information search, information sharing, responsible behaviour and personal interaction; citizenship behaviour is a voluntary behaviour outside the role, including feedback, advocacy, help and tolerance. The value co-creation behaviour is the behaviour generated by the integration of a series of consumption experiences, such as product use experience, consumption preference and behaviour tendency. Combined with the microsituation of private colleges and universities, this study believes that the value co-creation behaviour of students in private colleges and universities refers to the attitude change of students after receiving or participating in the service experience and the behaviour of creating value for the school, for example, students' initiative to recommend the college or and university to relatives and friends around, or actively answer questions about it on the Internet, etc. after obtaining satisfactory education services in a college or university, or other initiatives of students to invest their own resources to achieve the development of colleges and universities.

\subsection{Present Situation of Value Co-creation Theory of Students in Private Colleges and Universities}

Marketing Science Institution (2016) points out that consumer value co-creation has become one of the research focuses in the field of marketing and education in recent years, but there are still few value co-creation theories combined with private colleges and universities. Enterprises can obtain innovative thinking and considerable economic benefits through the value co-creation behaviour of consumers. For students, the process of value cocreation can promote them to get a sense of achievement and honour. And after this kind of deep communication and interaction, the enterprise is no longer a simple relationship between supply and demand in the hearts of customers, but a kind of emotional connection has been established between the two through value co-creation. This emotional connection will further influence the overall value of the enterprise, such as the value brought to the enterprise through the improvement of customer loyalty and the enhancement of purchase intention.

However, the value co-creation behaviour of students in private universities in China has not been fully paid attention to, and there are few researches on the causes of the value co-creation behaviour of students in private universities. As a result, many private colleges and universities in China are faced with the dilemma of having many majors which have no characteristics and are not outstanding. One of the important reasons for this 
predicament is that colleges and universities have not made full use of the value of consumers to deeply explore the needs of consumers. Secondly, in the process of students' consumption, colleges and universities seldom take the initiative to investigate students' consumption experience, and usually deal with problems only after they are encountered by students, which will greatly reduce the service experience and satisfaction of students. Finally, in the process of publicity of colleges and universities, although some students participate in it to some extent, their participation is in small scale and a scattered way, and most of them only make occasional comments in the school forum, unable to have an impact on the decision-making of consumers.

\section{STUDY ON THE INFLUENCE OF STUDENTS' VALUE CO- CREATION BEHAVIOUR ON THE BRAND IMAGE OF PRIVATE COLLEGES AND UNIVERSITIES}

Against the background of education marketization, the relationship between private colleges and students is closer and more relevant than that between ordinary enterprises and consumers. The image and reputation of colleges and universities in society is the additional image of students in their life. The society generally agrees that a good university represents a high-quality student. Therefore, it is inevitable for students to pay attention to the image construction of their colleges and universities, which is a kind of desire to participate in social interaction and obtain membership, and a goal to realize self-value identification and self-satisfaction as an individual student. The pursuit of self-satisfaction is the main motivation of students' participation. So, how to strengthen this participation behaviour and to generate student citizenship behaviour? This research holds that efforts should be made in the following aspects. The first is the service quality of private colleges and universities, which is the core product provided by colleges and universities, and it is the basis of all attitudes of students to produce satisfaction and loyalty. The second is innovation ability, which is an important means to show the creativity and enterprise of the school and this kind of momentum can well stimulate the enthusiasm of students to create value co-creation behaviour. The third is professional ethics. "Teachers are those who impart knowledge and solve doubts". In traditional Chinese culture, teachers not only have a high status, but also have a very high moral requirement. In private colleges and universities, the overall professional quality of teachers is the key factor to build a harmonious teacher-student relationship and win the trust of students. The forth is social responsibility. Private colleges and universities should take the initiative to take social responsibilities, and such a responsible image will win them a better social reputation. Praise from the society will trigger the pride of students, and the heart of respect and pride from students' heart is an important reason for the generation of civic behaviour. The fifth is organizational culture, which represents the purpose and ideal pursuit of a school, is the normal life atmosphere of teachers and students, and the internal cause of the formation of the whole campus atmosphere. Good organizational culture featuring excellent organization style and united working atmosphere and so on can enhance the enthusiasm of the members and the cohesion of the team. The research believes that organizational culture, as a kind of value, affects the value behaviour of every member of an organization.

To sum up, it can be seen that private colleges and universities should put students in the first place in order to better serve students when improving service quality, innovation ability, cultivating teachers' professional ethics, assuming social responsibility and building organizational culture. The process of deeply exploring students' needs is a process of in-depth communication between colleges and students. This process is also the continuous improvement of the brand of the school. Through an empirical study on the impact of website functions on value co-creation of college students, Foroudi et al.(2019) pointed out that when an organization can provide students with services that can quickly and conveniently solve their practical problems, students are most likely to conduct value co-creation behaviours. And students' value co-creation behaviours will further bring obvious benefits to universities, such as the strengthening of brand reputation, improving the performance of the school, long-term improvement of its service quality and so on. In the context of education marketization, colleges and universities as service providers should meet the needs of students to the greatest extent, and determining the real requirements of customers is helpful for enterprises to provide customers with correct services expected by them (Fejza \& Sogojeva, 2017). Relying on the traditional value creation methods, colleges and universities have obviously 
been unable to meet the personalized needs of students. However, relying on students' participation behaviour, students' various needs disclosed when they search for information and share such information with colleges and universities in a timely manner can help private colleges and universities tailor education services according to the special needs of students, thus enabling them to obtain a unique experience throughout their entire educational career (Foroudi et al., 2019) and get a product that is more in line with their expectations. In this process, private colleges and universities have integrated resources in the continuous interaction with students, to make campus culture more diversified, give curriculum setting, professional training and other unique characteristics and meet the needs of target consumer groups. It is helpful for colleges and universities to establish a distinct brand image, attract more consumers, and improve the performance of private colleges and universities.

Secondly, students' civic behaviour demonstrates their role as creators of content. When they take the initiative to export text, audio and other content about the brand of their school, such spontaneous publicity behaviour is more convincing and effective than media advertising. The value co-creation behaviour produced by students can greatly influence the people around them and the potential consumers of colleges and universities, and this influence can be everlasting. It can be seen that universities around the world receive significant funding and publicity from their alumni. Every student who can produce value cocreation behaviour is the spokesperson of the brand image of colleges and universities in the society. Every word of their praise or recommendation will promote the promotion of the brand image of private colleges and universities in the society, accumulate more social reputation and promote its development. It can thus be seen that co-creation behaviour is a long-term friendly emotional energy for the image of colleges and universities formed by students.

\section{CONCLUSION}

In conclusion, this study believes that students' value co-creation behaviour has a positive impact on the brand image of private colleges and universities.

In view of the current problems in the influence of student value co-creation on the brand image of private colleges and universities, this study summarizes the countermeasures of building the brand image of private colleges and universities from the perspective of practice. It analyzes the relationship between brand image and students' value co-creation behaviour, so as to provide a theoretical basis for private colleges and universities to develop their own brand image strategies according to their own running practices, and to provide new references for colleges and universities to strengthen connotation construction, improve competitiveness and avoid risks through value co-creation theory. In this paper, the value co-creation theory is incorporated into the overall framework of the brand construction mechanism of private colleges and universities, seeking to establish a clear and scientific mechanism and process system in the overall construction of private colleges and universities, so as to achieve a healthy and sustainable development of private colleges and universities.

\section{AUTHORS' CONTRIBUTIONS}

This paper is independently completed by Yiheng Wang.

\section{REFERENCES}

[1] Aaker, D. A. (1996). Measuring brand equity across products and markets. California management review, 38(3), 1-32.

[2] Aaker, J. L. (1997). Dimensions of brand personality. Journal of marketing research, 34(3), 347-356.

[3] Barich, H., \& Kotler, P. (1991). A framework for marketing image management. MIT Sloan Management Review, 32(2), 94.

[4] Binsardi, A., \& Ekwulugo, F. (2003). International marketing of British education: research on the students' perception and the UK market penetration. Marketing Intelligence \& Planning, 21(5), 318-327.

[5] Chaudhry, H., Gupta, S., \& Chauhan, A. S. (2017). Concept of Brand in Higher Education.Vilakshan: The XIMB Journal of Management, 14(2).

[6] Chen, C. C., Chen, P. K., \& Huang, C. E. (2012). Brands and consumer behavior. Social Behavior and Personality: an international journal, 40(1), 105-114. 
[7] Ennew, C. T., \& Binks, M. R. (1999). Impact of participative service relationships on quality, satisfaction and retention: an exploratory study. Journal of business research, 46(2), 121-132.

[8] Fan, W., \& Liang, Y. (2020). The impact of school autonomy and education marketization in the United Kingdom. Journal of Policy Modeling, 42(5), 1038-1048.

[9] Fejza, E., Sogojeva, M., \& Fejza, L. (2017). Analysis of service quality and customer satisfaction in hospitality. Case study: MICE Hotels in Kosovo. Journal of Management Cases, 47.

[10] Foroudi, P., Yu, Q., Gupta, S., \& Foroudi, M. M. (2019). Enhancing university brand image and reputation through customer value cocreation behaviour. Technological Forecasting and Social Change, 138, 218-227.

[11] Foroudi, P., Yu, Q., Gupta, S., \& Foroudi, M. M. (2019). Enhancing university brand image and reputation through customer value cocreation behaviour. Technological Forecasting and Social Change, 138, 218-227.

[12] Hemsley - Brown, J., \& Oplatka, I. (2006). Universities in a competitive global marketplace. International Journal of public sector management, (1), 316-338.

[13] Hewer, P., Brownlie, D., \& Kerrigan, F. (2013). 'The exploding plastic inevitable': 'Branding being', brand Warhol \& the factory years. Scandinavian Journal of Management, 29(2), 184-193.

[14] Lengnick-Hall, C. A. (1996). Customer contributions to quality: A different view of the customer-oriented firm. Academy of management review, 21(3), 791-824.

[15] Lin, Y. H., Lin, F. J., \& Wang, K. H. (2020). (in press). The effect of social mission on service quality and brand image. Journal of Business Research.

[16] Marconi, J. (1993). Beyond branding: how savvy marketers build brand equity to create products and open new markets. Probus Publishing Company, 201-203.

[17] Prahalad, C. K., \& Ramaswamy, V. (2004). Co - creation experiences: The next practice in value creation. Journal of interactive marketing, 18(3), 5-14.

[18] Schivinski, B., Christodoulides, G., \& Dabrowski, D. (2016). Measuring consumers' engagement with brand-related social-media content: Development and validation of a scale that identifies levels of social-media engagement with brands. Journal of Advertising Research, 56(1), 64-80.

[19] Wilkins, S., \& Huisman, J. (2015). Factors affecting university image formation among prospective higher education students: The case of international branch campuses. Studies in higher education, 40(7), 1256-1272.

[20] Wilkins, S., \& Huisman, J. (2015). Factors affecting university image formation among prospective higher education students: The case of international branch campuses. Studies in higher education, 40(7), 1256-1272.

[21] Yi, Y., \& Gong, T. (2013). Customer value co-creation behavior: Scale development and validation. Journal of Business research, 66(9), 1279-1284. 